\title{
Further Information on Resident Longspurs in Saskatchewan
}

\author{
By Frank Roy, Saskatoon
}

In the June, 1958 issue of the Blue Jay I commented upon the rapid decrease of McCown's and Chestnut-collared Longspurs in the Lucky iake-Birsay area, tucked within the elbow of the South Saskatchewan River. My observations elsewhere in the southern half of the province had led me to believe that the decrease was provincewide.

A number of members have written and in every instance they have a different story to tell. Bob Caldwell of Swift Current finds the Chestnut-collared Longspur very numerous in the southwest corner of the province, especially south of the Cypress Hills in the vicinity of Robsart, Climax, and Govenlock. Mr. George Fairfield, writing from Toronto, confirms Mr. Caldwell's observations. On June 18, 1958 Mr. Fairfield and his wife found Chestnutcollars common along Highway 21 between Cypress Lake and Vidora. Along this stretch of highway they counted 30 birds, most of them singing males.

George Ledingham of Regina, in the company of J. Hudson, found McCown's and Chestnut-collars very abundant in the area between Cottonwood Creek, south of Bracken, and Old Man On His Back Plateau, and in the Canopus-Killdeer area on May 18 and 19, 1958.

David Chandler, writing from Masefield just south of Val Marie, has noted no decline in numbers since he began birding there in the spring of 1948. He finds the Chestnutcollared Longspur to be the predominant species, and he says that it is still a common bird.

From other parts of the province, information is much less complete. George Ledingham says that both species are still fairly common in the Regina-Moose Jaw region, and that there are still "lots" of these birds on their farm, six miles west of Moose Jaw. On June 19, George Fairfield observed six male and two female McCown's Longspurs, and seven male and one female Chest- nut-collared Longspur in a field just north of the Moose Jaw golf course. The female Chestnut-collar was flushed off a nest containing five eggs.

Bob Nero states that on a trip from Regina to Big Muddy Lake, May 2324,1958 , he found the Chestnutcollared Longspur to be abundant "on and along the road where pasture land adjoined."

From the central portion of the province, we have the report of $P$. L. Beckie of Bladworth in the June, 1958 issue of the Blue Jay. He says that the Chestnut-collar is a common summer resident, but that $\mathrm{Mc}-$ Coun's has been recorded only three times, and in every instance in spring migration only. Bladworth is about 50 miles northwest of the Coteau region where I have recorded such a sharp decline in the numbers of both species. Farther east, Margaret Belcher reports that the Chestnutcollars are holding their own in the lake pastures east of Dilke and Holdfast, just west of Last Mountain Lake.

To return to the Lucky Lake-Birsay area, I find little or no change in the Longspur situation. Only three birds (all Chestnut-collars) were observed in the course of 260 miles driving within the area from May 16 to May 18, 1958. On June 28-29, these birds were observed in only one spot, just north of Lucky Lake at the base of the Coteau Hills. Even there, they were not common, perhaps four pairs to a quarter-section, and this in a limited pasture extending three miles along the lake shore.

There seems little doubt that both species are still common in much of the southern part of the province, particularly in the extreme southwest corner, south of the Cypress Hills. In view of this, I find it difficult to account for the pronounced decline in their numbers north of the South Saskatchewan River, but the fact remains: longspurs, once the most common bird in the Coteau, are now a rare and local species. 